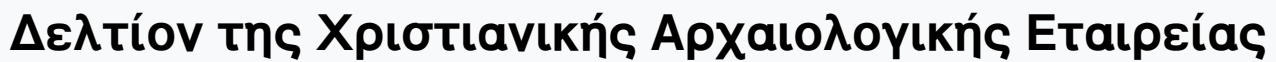

Tó 20 (1999)

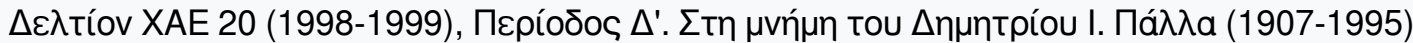

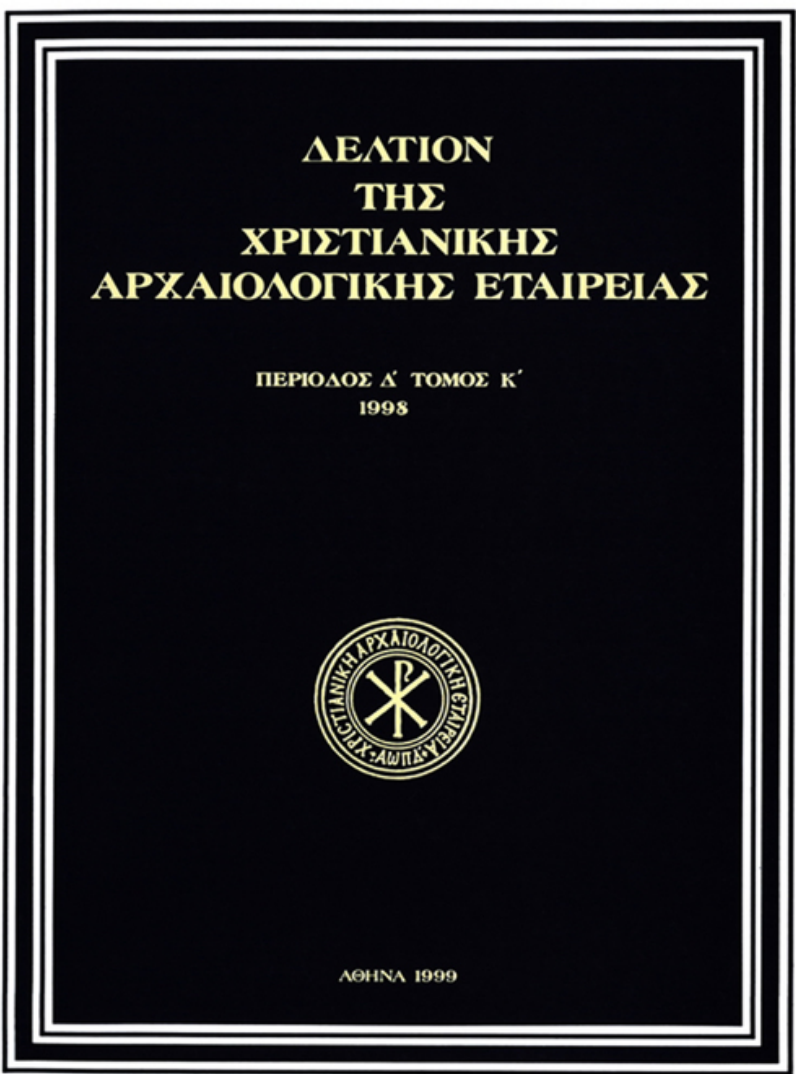

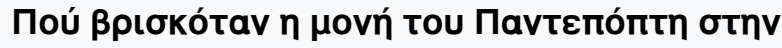
Kwvotavtıvoúroגn;

Cyril MANGO

doi: $\underline{10.12681 / \text { dchae. } 1196}$

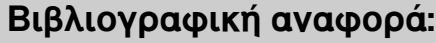

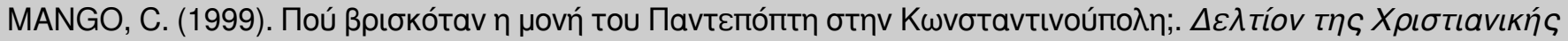
Архаıолоүıки́s Eтаıрві́as, 20, 87-88. https://doi.org/10.12681/dchae.1196 


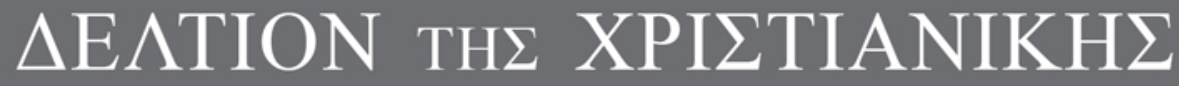 APXAIO $\Lambda$ OГIKH $\Sigma$ ETAIPEIA $\Sigma$}

Where at Constantinople was the Monastery of Christos Pantepoptes?

Cyril MANGO

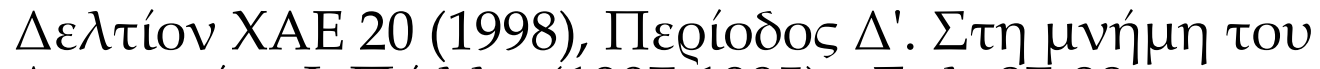

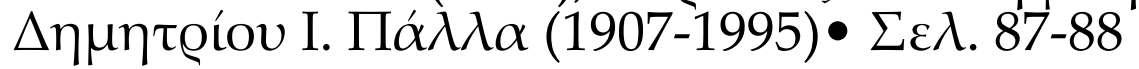

A@HNA 1999 


\section{Cyril Mango}

\section{WHERE AT CONSTANTINOPLE WAS THE MONASTERY OF CHRISTOS PANTEPOPTES?}

$T_{\text {he }}$ Christos Pantepoptes, founded by Anna Dalassena, with Eski İmaret Camii has been defended by A. van Millingen on the following grounds: 1 . Tradition, which "in the case of a building so conspicuous can scarcely be mistaken"; 2 . Its position on a hill commanding an extensive view of the Golden Horn, which the Pantepoptes monastery is said to have enjoyed; 3 . The architectural features of the building, which are consonant with an early Comnenian date ${ }^{1}$. No dissent has since been expressed, although Ebersolt does not seem to have been entirely convinced ${ }^{2}$.

As to the first point, it may well be doubted that a genuine tradition ever existed to that effect. Millingen quotes only the Patriarch Konstantios who, in the second edition of his $K \omega \nu$ -

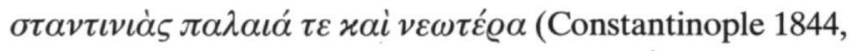
p. 106-7) does equate Pantepoptes with Eski İmaret Camii, even if he places the latter "not far from the walls [of the Golden Horn]", hardly an exact description. The first edition of the same work (Venice 1824), in its chapter devoted to churches converted into mosques, says nothing at all about Pantepoptes, which suggests that the Patriarch was unaware of it at the time. A little earlier J. von Hammer had wrongly alleged that Pantepoptes corresponded to Fethiye Camii ${ }^{3}$, whilst Charles Texier, who drew the first plan of Eski İmaret Camii between 1833 and 1835, labelled it "Monasterium Libis" (i.e. the monastery of Constantine Lips, now Fenari İsa Camii) ${ }^{4}$. In other words, there was no consensus at the time concerning the Byzantine name of Eski İmaret Camii. I am not aware of any mention of the building by a western traveller before the 19th century. I would suggest, therefore, that Konstantios simply made a guess based on the testimony

1. Byzantine Churches in Constantinople, London 1912, p. 212.

2. J. Ebersolt and A. Thiers, Les églises de Constantinople, Paris 1913, p. 181-2.

3. Constantinopolis und der Bosporos, Pesth 1822, I, p. 381.

4. His drawing as been reproduced by me in JdI 80 (1965), p. 326.

5. Nicetae Choniatae, Historia (ed. van Dieten), Berlin 1975, p. 568. of Niketas Choniates, which brings us to the second argument.

At first sight, this appears a little more convincing, for it is recorded by Niketas that in April 1204, when the Crusaders mounted their naval attack on the walls of the Golden Horn, Alexios Mourtzouphlos pitched his tent "on the hilltop by the monastery of Pantepoptes, whence the warships were visible and one could observe what was being done by their crews". The Crusaders' ships, we are told, were drawn up between the monastery of Evergetes (probably Gül Camii) and the Blachernai palace ${ }^{5}$. The eyewitness account contained in the First Novgorod Chronicle gives the same details: "facing St. Saviour called Vergetis (opposite Ispigas) as far as Lakherna"6. Whilst it is true that the site of Eski İmaret Camii does command a view of the Golden Horn, that view falls far short of Blachernai. A more obvious place for observing the actions of the Crusaders would have been the high platform now occupied by the mosque of Sultan Selim, which would also accord better with the statement of Niketas that Mourtzouphlos was stationed opposite the Petrion ${ }^{7}$. Likewise, the Novgorod Chronicler says that the Greek emperor's position was "near St. Saviour” (u svjatogo Spasa). Sultan Selim is almost directly above Gül Camii.

As to the third argument, it is undoubtedly true that the architectural features of Eski İmaret Camii would fit a construction date in the late 11th century, but many other monasteries were built at Constantinople during that period. In short, the traditional identification has little in its favour.

A short document that has escaped attention confirms what we have already suspected in connection with the events of April 1204. It is a list of the Seven Wonders contained in cod.

6. Novgorodskaja Pervaja Letopis', ed. A. N. Nasonov, Moscow - Leningrad 1950, p. 48. Latin translation in C. Hopf, Chroniques grécoromanes, Paris 1873, p. 96.

7. Op.cit., p. 569. On the situation of the Pertion see A. Berger, Untersuchungen zu den Patria Konstantinupoleos, Bonn 1988, p. 491. 
Matrit. gr. 86 (late 15th century), fol. 1v and has been published as follows:

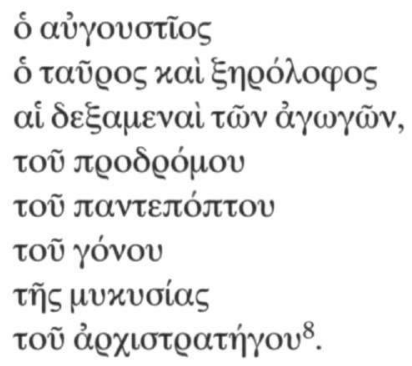

Let us begin by making two obvious corrections: toṽ yóvov

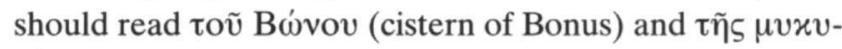
oías, as the editor has already seen, stands for $\tau \tilde{\eta} \varsigma \mathrm{M} \omega x \eta$ бias (cistern of St. Mokios). We should, therefore, place a colon after $\tau \tilde{\omega} v \stackrel{\alpha}{\alpha} \gamma \omega \gamma \tilde{\omega} v$ and consider the five following items as designating cisterns, more particularly open-air cisterns. The total number of wonders being seven, it seems

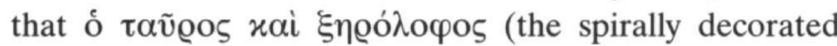
columns of Theodosios and Arkadios) count as a unit, whilst

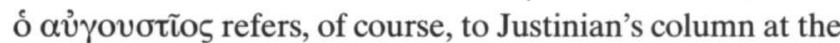
Augustaion.

The first of the five cisterns, that of the Prodromos, can readily be identified as that of Aetios, near the Adrianople gate, so named after the adjoining monastery of St. John in

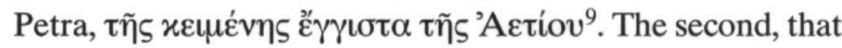
of Pantepoptes, can only be, in my opinion, that of Aspar at Sultan Selim. The cistern of Bonus, which has been the subject of lengthy debate, was north or north-east of the church of the Holy Apostles and may well have been the one in which Mehmed II built his bath, known as the Sunken Bath (Çukur Hamam), whose situation is known, although the bath has left no trace ${ }^{10}$.

The last cistern, that of St. Michael, is a little more problematic. The only other large-scale, open-air cistern that is known to me within the city walls was at the Turkish Saddlers' Market (Saraçhane), south-east of the Holy Apostles ${ }^{11}$. It has now disappeared, but was measured by Forchheimer and Strzygowski, who give its dimensions as $154 \mathrm{~m}$. from north to south by 90 from east to west, and identify it, not implausibly, with the 4th-century Cisterna Modestiaca ${ }^{12}$. No major church of St. Michael is, however, known to have stood in that vicinity. The name, I would suggest, was due to St. Michael's Column, i.e. the column upon which Michael VIII Palaiologos set up a statue of the Archangel together with his own kneeling effigy. This singular monument is known to have been near the church of All Saints, hence pretty close to Saraçhane ${ }^{13}$.

To sum up, the monastery of Christos Pantepoptes was situated roughly on the site of the Sultan Selim mosque, a position that fully justified its name. Another identity should be sought for Eski İmaret Camii. We may also note that of five cisterns, all of them major urban landmarks, three had lost their original name by the Palaiologan period. The implications of this phenomenon will have to be explored on another occasion.
8. K. Brodersen, Reiseführer zu den sieben Weltwundern, Frankfurt a. Main 1992, p. 154-5. Previously edited by J. Iriarte, Reg. bibl. Matritensis codd. graeci MSS, I, Madrid 1769, p. 232.

9. See R. Janin, Les églises et les monastères [de Constantinople], 2nd ed., Paris 1969, p. 427.

10. P. Gyllius, De topographia Constantinopoleos, iv. 2, Lyon 1561, p. 185: "Sub horum aedificiorum claustro [the Fatih complex] idem Mamethes thermas construxit totius urbis maximas in solo cisternae antiquae". Cf. J.-B. Lechevalier, Voyage de la Propontide et du PontEuxin, I, Paris 1800, p. 108: "On trouve les ruines d'une autre [citerne] près de Tchikour-Hamam, sur le penchant septentrional de la quatrième colline". For relevant indications see article Çukur Hamam by S. Eyice, İstanbul Ansiklopedisi, II, Istanbul 1994, p. 538. The bath was situated opposite the Baş Karadeniz Medresesi, the southernmost of the four medreses on the east side of the Fatih complex.
11. Gyllius, op.cit., p. 184: "fundamenta quaedam Cisternae... in cuius quidem cisternae solo sunt officinae, et tabernae Ephippiorum circiter ducentae". The Saraçhane is marked on the street map of Istanbul of c. 1880: E. H. Ayverdi, 19. asirda İstanbul haritası, Istanbul 1958, sheet $\mathrm{C} 4$.

12. Ph. Forchheimer and J. Strzygowski, Die byzantinischen Wasserbehälter von Konstantinopel, Vienna 1893, p. 52, 140, 152-3.

13. On St. Michael's Column see A.-M. Talbot, The Restoration of Constantinople under Michael VIII, DOP 47 (1993), p. 258-60 and my remarks in Studies on Constantinople, Aldershot 1993, Study X, p. 1013. For the church of All Saints see W. Müller-Wiener, Zur Lage der Allerheiligen-Kirche in Konstantinopel, Lebendige Altertumswissenschaft. Festgabe H. Vetters, 1985, p. 333-5, who identified its foundations south-east of the Fatih mosque. 